\section{Nitrite Toxicity to Plants}

IT is generally believed that nitrite is an intermediate product in the conversion of ammonium to nitrate in the soil where the conversion of nitrite to nitrate is important since relatively small quantities may have toxic effects on plant growth. Nitrite is not a stable intermediate and few cases of nitrite accumulation in soils are reported. Greaves et al. ${ }^{1}$ found that the maximum concentration of nitrite in an irrigated field in Utah did not exceed $17 \mathrm{lb}$. per acre; Feher and $\mathrm{Vigi}^{2}$ found $0 \cdot 27-1 \cdot 14 \mathrm{mg}$ nitrite per $\mathrm{kg}$ in Hungarian alkaline soils, and Janssen and Metzger ${ }^{3}$ found 0.25 p.p.m. in Arizona rice fields. Sokloff and Klotz ${ }^{4}$ reported as much as 70 p.p.m. of nitrite accumulated on Romana clay loam in California after a large application of organic matter and nitrogen in the form of nitrate. Nitrite only accumulated in neutral or alkaline soils, probably because its conversion to nitrate is inhibited more than the conversion of ammonia to nitrite. Fraps and Sterges ${ }^{5}$ found that nitrites accumulated in certain soils when calcium or magnesium carbonate was added.

A series of experiments was carried out in Nigeria to find the most suitable nitrogen fertilizer for some nitrogen deficient soils, and sodium nitrite was among the test compounds used. The soil was a sandy loam of $p \mathrm{H} \mathbf{5}^{\cdot 6}$. Guinea grass was planted in plastic pots and sodium nitrite applied, with or without lime, at a concentration of 40, 80 and 120 p.p.m. per pot. The sodium nitrite was applied when the plants were about $12 \mathrm{~cm}$ high to avoid killing off the seedlings. There were 6 plants in each pot and treatments were carried out in duplicate. After 5 weeks the plants were gathered, dried and nitrogen was determined. Table $\mathbf{I}$ gives the details of the results.

Table 1. Yield and Phosphords Contents of guinea Grass

\begin{tabular}{|c|c|c|c|c|c|c|c|}
\hline \multicolumn{3}{|c|}{ Treatment } & $\begin{array}{l}\text { Weight of } \\
\text { calcium } \\
\text { carbonate } \\
\text { applied }(g)\end{array}$ & $\begin{array}{l}\text { Height } \\
(\mathrm{cm})\end{array}$ & $\begin{array}{c}\text { Dry } \\
\text { matter } \\
\text { per plant } \\
(\mathrm{g})\end{array}$ & $\begin{array}{l}\text { N-content } \\
\text { per plant } \\
(\mathrm{mg})\end{array}$ & $\begin{array}{c}p \mathrm{H} \text { of soil } \\
\text { after } \\
\text { harvest }\end{array}$ \\
\hline Control & & & - & 25 & 0.08 & 0.8 & $5 \cdot 65$ \\
\hline Sodium nitrite & 40 & p.p.m. & - & 60 & $0 \cdot 20$ & $15 \cdot 8$ & $6 \cdot 02$ \\
\hline , & 80 & ", & - & 52 & $0 \cdot 13$ & 8.9 & $6 \cdot 30$ \\
\hline , & 120 & 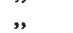 & - & 44 & $0 \cdot 10$ & $8 \cdot 2$ & $6 \cdot 40$ \\
\hline$"$ & 40 & $"$ & $2 \cdot 5$ & 31 & 0.07 & $2 \cdot 9$ & $6 \cdot 40$ \\
\hline ," & 80 & , & $2 \cdot 5$ & All dead & & & $6 \cdot 60$ \\
\hline$"$ & 120 & , & $2 \cdot 5$ & All dead & & & $6 \cdot 85$ \\
\hline ", & 40 & , & 1.25 & 27 & 0.02 & $2 \cdot 8$ & $6 \cdot 05$ \\
\hline ," & 80 & , & $1 \cdot 25$ & 23 & 0.03 & $1 \cdot 7$ & $6 \cdot 15$ \\
\hline$"$ & 120 & $"$ & $1 \cdot 25$ & All dead & & & 6.55 \\
\hline Ammoniu & & & & & & & \\
\hline sulphate & 40 & , & - & 67 & 0.23 & $14 \cdot 5$ & $5 \cdot 20$ \\
\hline , & 80 & , & - & 69 & $0 \cdot 30$ & $21 \cdot 8$ & $4 \cdot 25$ \\
\hline ", & 120 & ," & - & 74 & 0.38 & $22 \cdot 3$ & $4 \cdot 20$ \\
\hline
\end{tabular}

The smallest quantity (40 p.p.m.) of sodium nitrite was as good as ammonium sulphate, in the absence of lime. regarding yield and nitrogen absorption. This is in agreement with the conclusions of Schutz ${ }^{6}$ that plants absorb dilute nitrite more easily than nitrate. Perciabosco and Rosso ${ }^{7}$ also found that plants accumulated a higher percentage of nitrogen when supplied with nitrite. At a concentration of 80 p.p.m. there was a marked decrease in the height, yield and nitrogen content of the test plants. At the highest concentration three of the plants died, which suggested nitrite toxicity, and the three surviving plants decreased in height, yield and nitrogen content as with the previous concentration of sodium nitrite. Curtis $^{8}$ found that avocado leaves wilted at nitrite concentrations of 50 and 100 p.p.m. and finally died.

The lime required by the soil was determined by the standard calcium nitrophenol method and was found to be $2.5 \mathrm{~g}$ per pot. Two concentrations of lime were therefore applied, $2.5 \mathrm{~g}$ per pot and $1.25 \mathrm{~g}$ per pot. The lower concentration caused the plants treated with 40 and 80 p.p.m. sodium nitrite to grow no better than the controls, although they contained more nitrogen in dry matter.
Plants treated with 120 p.p.m. sodium nitrite all died before the end of the experiment. The higher concentration of lime gave the plants receiving 40 p.p.m. sodium nitrite no advantage over the controls, while those receiving 80 and 120 p.p.m. sodium nitrite died. The explanation might be that the lime increased the soil $p \mathbf{H}$ and the higher the $p \mathrm{H}$ the slower the conversion of nitrite to nitrate so that the possible toxic effect of the nitrite is greater. In this experiment lime increased the soil $p \mathrm{H}$ from 6.02 to 6.85 with the larger application of lime, and to 6.55 with the smaller application. Sokloff and $\mathrm{Klotz}^{4}$ have also reported severe injury to roots of citrus grown on slightly alkaline California soil containing 40 p.p.m. nitrite or less. The tolerance to nitrite will presumably vary for different plants and climatic conditions.

\section{О. L. Оке}

Department of Chemistry,

University of Ife,

Ibadan Branch,

Ibadan, Nigeria.

${ }^{1}$ Greaves, J. E., Stewart, R., and Hirst, C. T., Soil Sci., 8, 149 (1917). 8 Feher, D., and Vigi, I., Biochem. Z., 174, 262 (1926).

${ }^{3}$ Jansen, G., and Metzger, W. H. J., Amer. Soc. Agron., 20, 459 (1928). 4 Sokloff, V. P., and Klotz, L. J., Calif. Citrogr., 28, 290 (1943).

'Fraps, G. S., and Sterges, A. J., Tex. Agr. Expt. Sla. Bull., 412, 1 (1930). 'Schutz, M., thesis, Konigsberg Univ. (1903).

'Perciabosco, P., and Rosso, U., Staz. Sper. Agr. Ital., 42, 5 (1909).

${ }^{8}$ Curtis, D. S., Soil Sci., 68, 441 (1949).

\section{Spore of Volvariella volvacea}

Volvariella volvacea is a mushroom of the tropies and subtropics grown extensively as a source of fresh vegetables in some South East Asian countries. In Western countries, so far as we know, it is little cultivated.

Singer" noted, "The developmental, cytological, and physiological characters of the padi straw mushroom are little known; nothing has been published on the geneties of this fungus, or on the phylogeny of the cultivated races". Since 1961, we have been interested in the cultivation and nutrient content of the mushroom, and a more intensive study of the morphogenesis has been carried out in the past year.

Fruiting bodies of the straw mushroom were collected from cultivated straw beds ${ }^{2}$ during development from the complete covering of the pileus by the velum to the emergence of the pileus revealing the hymcnium. During this time the gills changed colour from cream to light pink. These were fixed in $1: 3$ acetic alcohol for $30 \mathrm{~min}$ and stored in 70 per cent $(\mathrm{v} / \mathrm{v})$ alcohol at $4^{\circ} \mathrm{C}$. To investigate sporogenesis in the basidium, squash preparations were made using freshly diluted acetic orcein after hydrolysis of the tissue with hydrochloric acid. Fig. 1 shows the developmental stages of the basidium and basidiospores. Relative sizes and positions of nuclei and the density and movement of cytoplasm are evident. Fig. 2 shows the basidiospores in the tetrad, prepared by Day's method. Due to the varying pressure in different planes on each tetrad, the four spores may be arranged tightly or loosely. In some of the tetrads two spores only are seen in surface view.

The basidiospores of this species are asymmetrical and tend to be egg shaped, but spherical or ellipsoidal ones are not uncommon. The outlino of the spore depends on the direction of observation. The average length of egg shaped spores is $7-9 \mu$; the widest part is $5-6 \mu$ and the narrowest part 3-4 $\mu$ across. The spores have a smooth, thick covering, with a short, triangular spine at the narrow end. When viewed with a transmitted light microscope, the cell wall and cell content may be transparent, light yellow, pink or dark brown. The change of spore colour occurs during maturation. Under 